\title{
Application of the Watershed Sustainability Index to the Elqui river basin, North-Central Chile
}

\section{Aplicación del Índice de Sustentabilidad de Cuencas en la cuenca del río Elqui, Centro-}

\section{Ana Elizabeth Cortés ${ }^{1}$, Ricardo Oyarzún ${ }^{2,3}$, Nicole Kretschmer ${ }^{3}$, Henrique Chaves ${ }^{4}$, Guido Soto ${ }^{1}$, Manuel Soto ${ }^{1}$, Jaime Amézaga ${ }^{5}$, Jorge Oyarzún $^{2}$, Tobias Rötting ${ }^{5,6}$, Michelle Señoret ${ }^{1}$ and Hugo Maturana ${ }^{2}$}

\footnotetext{
${ }^{1}$ Water Center for Arid and Semi-Arid Zones in Latin America and the Caribbean CAZALAC, Benavente 980, La Serena, Chile, anaelizabethc@gmail.com,gsoto@cazalac.org,msoto@cazalac.org,michelle.senoret@gmail.com

2Departamento Ingeniería de Minas, Universidad de La Serena, Benavente 980, La Serena, Chile, hmaturan@userena.cl, joyarzun@userena.cl

${ }^{3}$ Centro de Estudios Avanzados en Zonas Áridas CEAZA, Universidad de La Serena, Raúl Bitrán s/n, Colina El Pino, La Serena, Chile, royarzun@userena.cl, nicole.kretschmer@ceaza.cl

${ }^{4}$ Departamento de Ingeniería Forestal, Universidad de Brasilia, SQN 206 Bloc F Apt. 301, 70844.060 Brasilia, DF, Brasil,

hlchaves@terra.com.br

${ }^{5}$ School of Civil Engineering and Geosciences, Newcastle University, Newcastle upon Tyne NE1 7RU, UK,

Jaime.Amezaga@ncl.ac.uk

${ }^{6}$ Technical University of Catalonia UPC BarcelonaTech, Department of Geotechnical Engineering and Geosciences, Campus

Nord, Modulo D2, c/ Jordi Girona 1-3, 08034 Barcelona, Spain, tobias.roetting@upc.edu
}

The Watershed Sustainability Index WSI, developed as an integrated method to assess the sustainability of basin management, and particularly water resource management, was applied in the Elqui River Basin over a period of five years (2001-2005). The Elqui watershed is located in a semiarid region of Chile, and it has been incorporated into the River Basin Network of the UNESCO HELP Program. The result was an overall WSI score of 0.61 (within a possible range of 0 to 1), rating the basin sustainability as "intermediate". The main watershed strengths were related to the Environment and Policies indicators. On the other hand, the weakness observed in the watershed was related to the Hydrology indicator, mainly due to water scarcity issues. The bottlenecks and limitations identified in this study represent a window of opportunity to improve the current situation in the basin, and calls for more efficient coordination between the different institutions involved in natural resource management. The application of the WSI in the Elqui basin demonstrated the practicality of the method, both as an analytic instrument, and as a useful management tool for water authorities, water users and stakeholders. An important limitation encountered in this study, however, was a general lack of up to date local information. This needs to be addressed in applying the method for mid- to long-term planning and management strategies, both in the Elqui basin and elsewhere.

Keywords: integrated watershed management, hydrology, environment, quality of life, policies
El índice WSI, desarrollado para estimar la sustentabilidad de una cuenca en forma integrada con énfasis en la gestión de recursos hídricos, fue determinado en la Cuenca del Río Elqui considerando un período de 5 años (2001-2005). La cuenca del Río Elqui se ubica en una región semiárida de Chile, y ha sido incorporada a la red de cuencas hidrográficas del programa HELP de la UNESCO. El resultado fue un valor global de 0.61 para el indicador WSI (en el rango de 0 a 1), calificando el nivel de sustentabilidad como "intermedio". Las mayores fortalezas de la cuenca se relacionaron con los indicadores de Ambiente y de Politicas. Por otro lado, las mayores debilidades observadas en la cuenca se relacionaron con el indicador de Hidrología, debido principalmente a la situación de escasez hídrica. La identificación de estas limitantes representan una oportunidad para mejorar la actual situación en la cuenca, lo que obliga a una coordinación más eficiente entre las diferentes instituciones involucradas en la gestión de los recursos naturales. La aplicación del WSI a la Cuenca de Elqui demostró su utilidad como instrumento analítico asi como herramienta de gestión para autoridades relacionadas con el agua, usuarios y grupos de interés. Sin embargo, la actualización de la información local es necesaria para la planificación a mediano y largo plazo y la formulación de estrategias de desarrollo para esta cuenca y otras.

Palabras clave: gestión integrada de cuencas, hidrología, ambiente, calidad de vida, politicas 


\section{Introduction}

The Brundtland Report in 1987 (Brundtland, 1987) and the 1992 Rio Declaration on Environment and Development laid the foundations for sustainable development (Hezri and Hasan, 2006). New environmental governance frameworks subsequently began to emerge, based on growing recognition of the need for development-aimed actions that meet the needs of both current and future generations in an equitable manner (Machinea et al., 2005). It was accepted that sustainable development should not only stimulate economic growth, but it should also promote the equitable distribution of wealth, prioritize environmental issues, and empower people rather than marginalizing them (UNDP, 1994).

Chile has adopted these concepts, and since 1994 the country has had a system of public environmental management, which has been subject to a number of recent reforms (Lostarnau et al., 2011). Moreover, Chile also recently joined the Organization for Economic Co-operation and Development OECD, a move that triggered the emergence of a number of new natural resource management policies. Collectively, these developments suggest that environmental issues have started to gain increasing importance in the country, and that there has been a general improvement in environmental policies and actions. Within this context, a topic that has gained increasing prominence is that of integrated watershed management and water resources protection, underscored by the formulation of three recent policy instruments: the National Strategy for Integrated Watershed Management (CONAMA, 2007), the National Glacier Policy (CONAMA, 2009), and the Secondary Surface Water Quality Regulations (CONAMA, 2004). The general objective of the National Strategy for Watershed Management is "to protect water resources, both in terms of quantity and quality, in order to safeguard human consumption and harmonize conservation objectives of ecosystems with the sustainable use of water resource by economic activities" (CONAMA, 2007), and has direct bearing on the subject of this paper.

As Perlack et al. (2001) stated, "watersheds comprise highly complex systems that provide a major challenge to those who would attempt to understand and control them". Although the integrated watershed management approach includes several factors, resources, and stakeholders, the issue of water resources tends to be one of the key components of the system, because water confers territorial integrity and connectivity to a basin, and it is a central determinant of the health and character of ecosystems (Saravanan et al., 2009). Indeed, water management actions, particularly important in arid and semi-arid areas where water resources are scarce, must consider sustainability issues. Thus, quantitative indicators and means of objective verification are critical in assessing the degree of application, development and outcomes of intervention strategies and natural resource use, as well as the extent to which sustainable development is realized (Hezri and Hasan, 2006; Hooper, 2010).

Sustainability indicators are means by which to assess the degree to which these criteria are met, since they help to translate abstract concepts into measurable parameters (Lee and Huang, 2007). In particular, they have become useful tools for water resources planning and management activities (Molle and Mollinga, 2003; Araral, 2010; Hooper, 2010), provided they fulfill certain preconditions: they should be easy to apply, comprehensive and universally applicable. In addition, they must be useful beyond administrative boundaries, and must consider cause-effect relationships (Chaves and Alipaz, 2007). Last but not least, they must be quantifiable, remain sensitive to changes in time and space, and amenable to revision (Ledoux et al., 2005; Lee and Huang, 2007).

Although there are several environmental, sustainability, and water scarcity indices described in the literature (e.g. Molle and Mollinga, 2003; Sullivan et al., 2003; Ledoux et al., 2005; Lee and Huang, 2007), these are not basin-specific and are not designed to assess watershed sustainability with respect to integrated water resources management. Within this framework, the International Hydrology Program IHP of the United Nations Educational, Scientific and Cultural Organization UNESCO, through its Hydrology, Environment, Life and Policy HELP platform, started and supported the search and development of an index in line with its development strategy. The Watershed Sustainability Index WSI, was developed to meet these needs (Chaves and Alipaz, 2007). The WSI takes into account hydrologic, environmental, livelihood and policy issues in order to provide an integrated assessment of the current state of watershed management in a given basin for a specific period of time. 
In 2008 the Elqui river basin, located in arid North-Central Chile, was included in the HELP worldwide watershed network program. One of the first initiatives carried out was to use the WSI approach to assess the prevailing level of sustainability and management practices adopted in the basin. The application of the WSI, which is presented in this contribution, was carried out as part of the working tasks of the UNESCO-supported Water Center for Arid and Semi-Arid Zones in Latin America and the Caribbean CAZALAC, within the framework of the Coquimbo Region Water Round Table lead by DGA-CAZALAC, and as part of the activities of the CAMINAR project (Catchment Management and Mining Impacts in Arid and Semi Arid SouthAmerica). CAMINAR was a research and development project funded by the European Commission as part of the $6^{\text {th }}$ Framework Program, executed between 2007 and 2010. Its general scope was "to contribute to the establishment of policy options, management strategies and technologies for the sustainable management of ecosystems in river-basins of arid and semi-arid South America which are subject to impacts from mining, using Peru, Bolivia and Chile as demonstration countries" (Amézaga et al., 2007). Three test cases were selected, comprising the Chili River (Peru), Poopoo Lake (Bolivia), and the Elqui River (Chile). Within this framework, a watershed sustainability index WSI was determined for the Elqui basin, which constitutes the main objective of this work. In addition to applying the WSI in the UNESCOHELP Elqui river basin, an analysis of the potential and limitations of the approach, and sustainability indicators in general, was also performed.

\section{Methodology}

\section{Area of study}

The Elqui river basin is located in North-Central Chile, between $29^{\circ} 27^{\prime}-30^{\circ} 34^{\prime} \mathrm{S}$ and $71^{\circ} 22^{\prime}-69^{\circ} 52^{\prime} \mathrm{W}$, covering an area of $c a .9700 \mathrm{~km}^{2}$ (Figure 1). It includes three subwatersheds: Turbio river ( $\left.c a .4200 \mathrm{~km}^{2}\right)$, Claro river ( $c a$. $1550 \mathrm{~km}^{2}$ ), and Elqui river (ca. $\left.3950 \mathrm{~km}^{2}\right)($ Oyarzun et al., 2006; Galleguillos et al., 2008). The Turbio river originates from the confluence of the Toro river, which drains the $\mathrm{Au}-$ $\mathrm{Cu}-\mathrm{As}$ mining district of El Indio, and the La Laguna river, the latter partly sustained by the melting of the receding El Tapado glacier. The Claro river originates from the confluence of the Derecho and Cochiguaz rivers. From the headwaters to the Pacific Ocean, the Elqui River system receives water contributions from several minor streams, some of them permanent and others ephemeral. The whole hydrological system extends between the Andean mountains and the Pacific Ocean over a length of only $150 \mathrm{~km}$. Thus, the watershed presents extreme altitude differences between its headwaters and its discharge point to the sea (i.e. about 5,000 $\mathrm{m}$ for a horizontal distance of only $150 \mathrm{~km}$ ), which favours the existence of turbulent river flows.

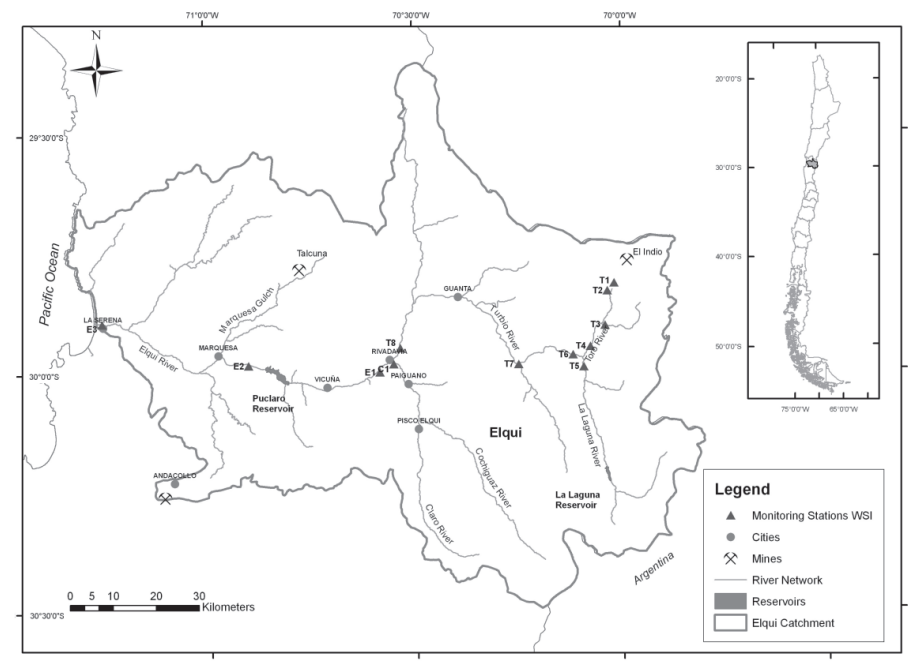

Figure 1: Elqui river basin with main tributaries, cities, mining districts and water monitoring stations (T1: Malo river after El Indio; T2: Baños del Toro; T3: Vacas Heladas river before Malo river; T4: Toro river before La Laguna; T5: La Laguna before Toro river; T6: Turbio river after La Laguna and Toro rivers; T7: Incaguaz river before Turbio river; T8: Turbio river at Varillar; C1: Claro river at Rivadavia; E1: Elqui river at Algarrobal; E2: Elqui river at Amendral; E3: Elqui river at La Serena)

Four major geomorphologic units are recognized in the Elqui basin (Paskoff, 1993): Andean High Mountains (elevations above $3000 \mathrm{~m}$ ), Middle Mountains (hills with elevations between 600 and $3000 \mathrm{~m}$, highly dissected with both non-permanent and permanent small discharge streams), Fluvial Valleys (E-W oriented terraces) and the Coastal Border (broad marine and fluvio-marine terraces).

The geology of the basin comprises Lower Paleozoic to Upper Tertiary, calco-alkaline plutonic and volcanic rocks (lava flows and pyroclastic rocks), with some marine, partly carbonatic sedimentary intercalations of Jurassic and Lower-Cretaceous age. The rocks are highly fractured and those of Cretaceous and Tertiary age present abundant 
mineral deposits $(\mathrm{Cu}, \mathrm{Au}, \mathrm{Ag}, \mathrm{Mn}, \mathrm{As})$ and hydrothermal alteration zones (Oyarzun et al., 1998, Oyarzún et al., 2003). Quaternary alluvial aquifers present relatively low yields, except in the lower course of the Elqui river valley. On the other hand, fractured and altered volcanic rock strata present medium permeabilities and thus behave as effective but low-transmissivity aquifers.

Climatic conditions are determined by the interaction of the orographic surface and the Pacific Ocean with the cold Humboldt Current and the south-eastern Pacific anticyclone, generally resulting in low precipitation restricted to the winter months. In the coastal zone and up to some $40 \mathrm{~km}$ inland, a Coastal steppe climate with abundant clouds prevails. In the Middle Mountains, above $800 \mathrm{~m}$ of altitude, there is a warm steppe climate, characterized by the lack of clouds and higher temperatures. Finally, in the Andean Cordillera area, above $3000 \mathrm{~m}$ of altitude, there is a moderate cold climate with higher precipitation, lower temperatures and permanent snow accumulations (Llanca and Miranda, 2003). Also, it is common to find local microclimates throughout the valley that allow the cultivation and growth of mediterranean and subtropical species such as papaya, mango, avocado, lemons, and grapes. An average annual rainfall of approximately 90 to $100 \mathrm{~mm}$ is experienced in the Coast and in the Middle Mountains areas. This figure is probably doubled in the Andean High Mountains where precipitation mainly falls as snow, although precipitation data are generally sparse and less reliable. A majority of the precipitation in the watershed occurs between May and August (UNESCO, 2010), and the highest runoff (controlled by snow-ice melting), takes place in spring-summer. Thus, both snow and ice constitute the source for the base discharge in the Elqui basin. Actual evapotranspiration ranges between 65 and $750 \mathrm{~mm} /$ year for native vegetation and irrigated agricultural crops respectively (Kalthoff et al., 2006).

River discharge in the Elqui River watershed is highly variable in both space and time. The Turbio River exhibits an annual average discharge between 0.8 and $7.1 \mathrm{~m}^{3} / \mathrm{s}$; in the Claro River the annual average discharge ranges between 1.5 and $4.5 \mathrm{~m}^{3} / \mathrm{s}$, while in the Elqui River it ranges between 4.3 and $12.5 \mathrm{~m}^{3} / \mathrm{s}$ (Galleguillos, 2004). Also, due to the ENSO cycle, the Elqui runoff has historically been highly variable (e.g. as low as 2.4 and as high as $33 \mathrm{~m}^{3} / \mathrm{s}$ or even greater). However, the existence of the Andean La Laguna reservoir (with an accumulation volume of 40 million $\mathrm{m}^{3}$ ), operating since 1941 , and the rather recent construction and operation (November 2002) of the Puclaro dam (200 million $\mathrm{m}^{3}$ of capacity) has contributed to regulate the Elqui river discharge, particularly in its lower course (Galleguillos et al., 2008).

Despite the arid and variable climatic conditions, the Elqui basin has undergone significant agricultural and agroindustrial development, supported by an extensive system of irrigation channels with a total irrigated area of 13.000 ha (Guevara et al., 2006). The agricultural production in the Elqui valley is now worth US\$40 million a year.

Historically, mining has also been important in the area. Three mining districts in the Elqui basin are of major importance, although they differ in terms of the type and relevance of their polluting effects on the watershed: the Andacollo, Talcuna, and El Indio districts. The Andacollo $\mathrm{Cu}$-Au district, connected to the Elqui valley from the South via El Arrayán creek, includes a 450 million ton copper deposit and important epithermal gold ore bodies (Higueras et al., 2004). The Talcuna copper district (Oyarzun et al., 1998), in the Quebrada Marquesa stream, north side of the Elqui River, has been responsible for several pollution episodes, by tailing deposit spills due to operational failures. Finally, El Indio Au-Cu-As district (Jannas et al., 1999) at the head of the basin, at an altitude above $4000 \mathrm{~m}$, is directly connected to the Rio del Toro, and therefore, to the Elqui river. Active from the mid 1970s until 1999, the mining company located in the area initiated a closure plan in 2003. However, the district, which is located on a belt of hydrothermal alteration zones, has been a natural source of acid drainage for at least 10,000 years, and delivers important loadings of $\mathrm{As}, \mathrm{Cu}, \mathrm{Zn}, \mathrm{Fe}$ and $\mathrm{SO}_{4}$ to the Rio del Toro water, which are largely in excess of the Chilean standard for irrigation water (Oyarzun et al., 2004).

\section{WSI Index and its application}

The WSI is described in detail in Chaves and Alipaz (2007) and UNESCO (2008). Thus, only the key aspects of the index, as well as some modifications performed within this contribution, are covered here.

The Watershed Sustainability Index is an integrated basin indicator, used to estimate basin sustainability, taking into 
account hydrological, environmental and socioeconomic issues. The WSI is given by (Chaves and Alipaz, 2007; UNESCO 2008):

$\mathrm{WSI}=(\mathrm{H}+\mathrm{E}+\mathrm{L}+\mathrm{P}) / 4$

where WSI (0-1) is the watershed sustainability index; $\mathrm{H}(0$ $-1)$ is the hydrologic indicator; $\mathrm{E}(0-1)$ is the environmental indicator; L (0-1) is the life (livelihood) indicator; and $\mathrm{P}$ $(0-1)$ is the policy indicator. All indicators have the same weight (Chaves and Alipaz, 2007).

Each indicator in equation (1) is obtained from appropriate tables, that consider factors such as Pressure (i.e. human activities that cause or can provoke impacts to the environment), State (i.e. situation of different aspects of the environment at a given moment), and Response (relating to the societal efforts to adress environmental problems and reclaim impaired systems). The advantage of using a Pressure-State-Response approach lies in the fact that it takes into account cause-effect relationships, allowing different stakeholders, managers, and decision makers to recognise and understand the interconnections between the parameters (OECD, 2003). The WSI indicators and parameters, including their levels and scores, are presented in Tables 1, 2, and 3.

Due to data availability and logistical issues, the WSI was determined at the Elqui river basin for the period 20012005. However, the parameters requiring long-term means were estimated for the period 1978-2005.

Table 2: State parameters, level, and scores of the Watershed

Table 1: Pressure parameters, level, and scores of the Watershed Sustainability Index

\begin{tabular}{|c|c|c|c|}
\hline Indicator & Pressure parameters & Level & Score \\
\hline \multirow{2}{*}{ Hydrology } & $\begin{array}{l}\Delta 1 \text {-variation in the basin per capita water availability in } \\
\text { the period studied, relative to the long-term average } \\
\left(\mathrm{m}^{3} / \text { person year) }\right.\end{array}$ & $\begin{array}{c}\Delta 1<-20 \% \\
-20 \%<\Delta 1<-10 \% \\
-10 \%<\Delta 1<0 \% \\
0<\Delta 1<+10 \% \\
\Delta>+10 \%\end{array}$ & $\begin{array}{l}0.00 \\
0.25 \\
0.50 \\
0.75 \\
1.00\end{array}$ \\
\hline & $\begin{array}{l}\Delta 2 \text {-variation in the basin } \mathrm{BOD}_{5} \text { in the period studied, } \\
\text { relative to the long-term average }\end{array}$ & $\begin{array}{c}\Delta 2>20 \% \\
20 \%>\Delta 2>10 \% \\
0<\Delta 2<10 \% \\
-10 \%<\Delta 2<0 \% \\
\Delta 2<-10 \%\end{array}$ & $\begin{array}{l}0.00 \\
0.25 \\
0.50 \\
0.75 \\
1.00\end{array}$ \\
\hline Environment & $\begin{array}{l}\text { Basin Environment pressure index (rural and urban) in } \\
\text { the period studied }\end{array}$ & $\begin{array}{c}\text { EPI }>20 \% \\
20 \%<\text { EPI }>10 \% \\
10 \%<\text { EPI }<5 \% \\
5 \%<\text { EPI }<0 \% \\
\text { EPI }<0 \%\end{array}$ & $\begin{array}{l}0.00 \\
0.25 \\
0.50 \\
0.75 \\
1.00\end{array}$ \\
\hline Life & $\begin{array}{l}\text { Variation in the basin per capita Human Development } \\
\text { Index (HDI)-Income in the period studied, relative to the } \\
\text { previous period }\end{array}$ & $\begin{array}{c}\Delta<-20 \% \\
-20 \%<\Delta<-10 \% \\
-10 \%<\Delta<0 \% \\
0<\Delta<+10 \% \\
\Delta>+10 \%\end{array}$ & $\begin{array}{l}0.00 \\
0.25 \\
0.50 \\
0.75 \\
1.00\end{array}$ \\
\hline Policy & $\begin{array}{l}\text { Variation in the basin HDI-Education } \\
\text { in the period studied, relative to the previous period }\end{array}$ & $\begin{array}{c}\Delta<-20 \% \\
-20 \%<\Delta<-10 \% \\
-10 \%<\Delta<0 \% \\
0<\Delta<+10 \% \\
\Delta>+10 \%\end{array}$ & $\begin{array}{l}0.00 \\
0.25 \\
0.50 \\
0.75 \\
1.00\end{array}$ \\
\hline
\end{tabular}


Sustainability Index

\begin{tabular}{|c|c|c|c|}
\hline Indicator & State parameters & Level & Score \\
\hline \multirow[t]{2}{*}{ Hydrology } & $\begin{array}{l}\text { Basin per capita water availability }\left(\mathrm{m}^{3} / \text { person year), }\right. \\
\text { considering both surface and groundwater sources }\end{array}$ & $\begin{array}{c}\mathrm{Wa}<1700 \\
1700<\mathrm{Wa}<3400 \\
3400<\mathrm{Wa}<5100 \\
5100<\mathrm{Wa}<6800 \\
\mathrm{Wa}>6800\end{array}$ & $\begin{array}{l}0.00 \\
0.25 \\
0.50 \\
0.75 \\
1.00\end{array}$ \\
\hline & Basin averaged long term $\mathrm{BOD}_{5}(\mathrm{mg} / \mathrm{l})$ & $\begin{array}{c}\mathrm{BOD}>10 \\
10<\mathrm{BOD}<5 \\
5<\mathrm{BOD}<3 \\
3<\mathrm{BOD}<1 \\
\mathrm{BOD}<1\end{array}$ & $\begin{array}{l}0.00 \\
0.25 \\
0.50 \\
0.75 \\
1.00 \\
\end{array}$ \\
\hline Environment & Percent of basin area under natural vegetation (Av) & $\begin{array}{c}\text { Av }<5 \\
5<\mathrm{Av}<10 \\
10<\mathrm{Av}<25 \\
25<\mathrm{Av}<40 \\
\mathrm{Av}>40\end{array}$ & $\begin{array}{l}0.00 \\
0.25 \\
0.50 \\
0.75 \\
1.00\end{array}$ \\
\hline Life & $\begin{array}{l}\text { Basin Human Development Index (HDI), } \\
\text { weighed by county population }\end{array}$ & $\begin{array}{c}\text { HDI }<0.5 \\
0.5<\text { HDI }<0,6 \\
0.6<\text { HDI }<0.75 \\
0.75<\text { HDI }<0.9 \\
\text { HDI }>0.9\end{array}$ & $\begin{array}{l}0.00 \\
0.25 \\
0.50 \\
0.75 \\
1.00\end{array}$ \\
\hline Policy & $\begin{array}{l}\text { Basin institutional capacity in Integrated Water Resources } \\
\text { Management (legal and organizational) }\end{array}$ & $\begin{array}{l}\text { Very poor } \\
\text { Poor } \\
\text { Medium } \\
\text { Good } \\
\text { Excellent } \\
\end{array}$ & $\begin{array}{l}0.00 \\
0.25 \\
0.50 \\
0.75 \\
1.00\end{array}$ \\
\hline
\end{tabular}

Table 3: Response parameters, level, and scores of the Watershed Sustainability Index

\begin{tabular}{|c|c|c|c|}
\hline Indicator & Response parameters & Level & Score \\
\hline \multirow{2}{*}{ Hydrology } & $\begin{array}{l}\text { Improvement in water-use efficiency in the basin, in the } \\
\text { period studied }\end{array}$ & $\begin{array}{l}\text { Very poor } \\
\text { Poor } \\
\text { Medium } \\
\text { Good } \\
\text { Excellent }\end{array}$ & $\begin{array}{l}0.00 \\
0.25 \\
0.50 \\
0.75 \\
1.00\end{array}$ \\
\hline & $\begin{array}{l}\text { Improvement in adequate sewage treatment/disposal in the } \\
\text { basin, in the period studied }\end{array}$ & $\begin{array}{l}\text { Very poor } \\
\text { Poor } \\
\text { Medium } \\
\text { Good } \\
\text { Excellent }\end{array}$ & $\begin{array}{l}0.00 \\
0.25 \\
0.50 \\
0.75 \\
1.00\end{array}$ \\
\hline Environment & $\begin{array}{l}\text { Evolution in basin conservation areas (Protected areas and } \\
\text { Best Management Practices) in the basin, in the period } \\
\text { studied }\end{array}$ & $\begin{array}{c}\Delta<-10 \% \\
-10 \%<\Delta<0 \% \\
0<\Delta<+10 \% \\
+10 \%>\Delta>+20 \% \\
\Delta>20 \%\end{array}$ & $\begin{array}{l}0.00 \\
0.25 \\
0.50 \\
0.75 \\
1.00\end{array}$ \\
\hline Life & $\begin{array}{l}\text { Evolution in the basin Human Development Index in the } \\
\text { basin, in the period studied }\end{array}$ & $\begin{array}{c}\Delta<-10 \% \\
-10 \%<\Delta<0 \% \\
0<\Delta<+10 \% \\
+10 \%>\Delta>+20 \% \\
\Delta>20 \%\end{array}$ & $\begin{array}{l}0.00 \\
0.25 \\
0.50 \\
0.75 \\
1.00\end{array}$ \\
\hline Policy & $\begin{array}{l}\text { Evolution in the basin's Water Resources Management } \\
\text { expenditures in the basin, in the period studied }\end{array}$ & $\begin{array}{c}\Delta<-10 \% \\
-10 \%<\Delta<0 \% \\
0<\Delta<+10 \% \\
+10 \%>\Delta>+20 \% \\
\Delta>20 \%\end{array}$ & $\begin{array}{l}0.00 \\
0.25 \\
0.50 \\
0.75 \\
1.00\end{array}$ \\
\hline
\end{tabular}




\section{Data}

The information required to determine the WSI for the Elqui river basin was obtained from several sources, such as available technical reports and public information, as well as through informal interviews with professionals and authorities of both public and private organizations and institutions of the Coquimbo Region. Further details are presented in Cortés (2010).

Hydrological information was mainly obtained from the Chilean Water Authority (Dirección General de Aguas, DGA), which manages a network of discharge and water quality monitoring stations placed throughout the basin (Figure 1). Also, the Elqui River Water Board (Junta de Vigilancia del Río Elqui y sus Afluentes) provided information on water diverted to irrigation channels and historic water reservoir levels. Information regarding water use efficiency investments in the basin was obtained from the National Irrigation Commission (Comisión Nacional de Riego, CNR) and the Coquimbo Region Government (Gobierno Región de Coquimbo, GORE-C). This information included detailed annual records of public works investment and subsidized farm irrigation projects (e.g. drip, trickle irrigation) in the form of Excel spreadsheets. In addition, a thorough literature search and analysis was carried out regarding water quality issues from previous studies carried out in the basin (e.g. Galleguillos, 2004; Guevara et al. 2006; Galleguillos et al. 2008; Espejo et al., 2012). Finally, interviews were held at the Sanitary Services Authority (Superintendencia de Servicios Sanitarios, SISS).

For the Environment component, information was obtained from Agricultural Activity and Demographic Census, which is carried out in Chile by the National Statistics Institute (Instituto Nacional de Estadisticas, INE) every ten years, although not simultaneously for both topics. Moreover, this information is provided for the municipality level (the lowest administrative division in Chile), and needs to be translated into the basin level. There was additional statistical information available at INE at the Region scale. Finally, interviews were held at the Chilean Environmental Commission (Comisión Nacional del Medio Ambiente, CONAMA), currently Environmental Ministry (Ministerio del Medio Ambiente), the Chilean Forestry Service (Corporación Nacional Forestal, CONAF) and the Chilean Agricultural and Livestock Service (Servicio Agrícola y Ganadero, SAG). These interviews conveyed valuable information, in particular regarding the current status of protected areas in the Coquimbo Region, where the Elqui basin is located.

Regarding the Life component, the Human Development Index HDI, of the United Nation's Development Program PNUD and related information was considered. The HDI covers aspects such as income, health and education. It is available at the municipality level. Although this information was not up to date, it was nevertheless used with this caveat in mind. In order to align the dates of data availability (1994, 1998, and 2003) with the period considered in this study, INE's demographic statistics and projections were used. Finally, regarding the Policy component, some of the information was retrieved from the sources already mentioned.

\section{WSI adaptations}

With respect to the WSI methodology, as described in Chaves and Alipaz (2007) and UNESCO (2008), some modifications were made in its application to the Elqui basin:

a) Spatial extent of the unit of analysis: although the original methodology suggests a maximum basin area of $2500 \mathrm{~km}^{2}$, the WSI was determined for the Elqui basin as a whole. This was done because some information existed only at the municipality level, and this administrative subdivision does not necessarily coincide with the subbasin delineation. It was therefore decided to aggregate the information at the Province scale given the fact that, at least in the Elqui basin, their boundaries are more coincident.

b) Water quality parameter: since the WSI methodology allows for the substitution of $\mathrm{BOD}_{5}$, originally considered in Chaves and Alipaz (2007), by other critical water quality parameters, Electric Conductivity EC was chosen instead. Although this parameter does not give specific information on the particular ions in the water, it could be of great help in detecting possible environmental impacts derived from mining or agriculture in the basin. Thus, the thresholds described in the Chilean water quality regulation, $\mathrm{NCh}$ 1333 (INN, 1987), the World Health Organization water quality regulation (WHO, 2008), as well as in the Chilean secondary water quality regulations (CONAMA, 2004) 
were considered. From this, levels and ranges were defined for the State component (Table 4).

Table 4: Levels and scores suggested for the electric conductivity in the Elqui river basin

\begin{tabular}{llcc}
\hline $\begin{array}{l}\text { Sub- } \\
\text { indicator }\end{array}$ & Parameter & Level & Score \\
\hline \multirow{4}{*}{ Water } & Long term & EC $>2250$ & 0.00 \\
quality & Electric & $2250>$ EC $>1600$ & 0.25 \\
& Conductivity EC, & $1600>\mathrm{EC}>750$ & 0.50 \\
& basin's average, & $750>\mathrm{EC}>600$ & 0.75 \\
& mmhos $/ \mathrm{cm}$ & $\mathrm{EC}<600$ & 1.00 \\
\hline
\end{tabular}

c) Environmental-Response parameter: this parameter considers the evolution in protected areas, but could not be determined in this study, as a result of the fact that no statutory protected areas (managed under the official Sistema Nacional de Areas Silvestres Protegidas del Estado, SNASPE) exist in the Elqui basin at present. However, there is a Governmental Program oriented towards the reclamation of degraded and/or eroded soils (the Sistema de Incentivos para la Recuperación de Suelos Degradados, SIRSD-Sustentable), which was considered as a suitable alternative for the Environmental Response parameter determination.

\section{Validation workshop}

After the initial data gathering, systematization and analysis, a stakeholder validation workshop of both the WSI methodology and the preliminary results was held with different local stakeholders, in particular those participating in the Coquimbo Region Water Round Table. This activity was especially useful for determining qualitative aspects considered by the WSI, such as those related to Policy-State parameters. The workshop was held on the $16^{\text {th }}$ and $17^{\text {th }}$ of November 2009 , with an attendance of 34 people.

\section{Results}

Since the WSI is computed on the basis of the scores of its four indices, each of them is presented separately, and the overall sustainability index (equation (1)) is obtained in the end.

\section{Hydrology Indicator}

The hydrology indicator score is the mean of the basin's water quantity and quality components. In the case of the former, the per-capita water availability (Hydrology-State) was derived from the sum of long-term mean river stream flow rate plus the available groundwater yield, estimated from the existing water rights, divided by the basin population in the period studied.

At the Algarrobal Station (downstream of the confluence of the Turbio and Claro rivers, E1 in Figure 1), the Elqui river has a long-term mean discharge of $12.9 \mathrm{~m}^{3} / \mathrm{s}$. In the case of groundwater, all the granted rights in the basin, being an estimation of groundwater use/availability, correspond to $7.9 \mathrm{~m}^{3} / \mathrm{s}$. Thus, the ratio of water yield ( 12.9 plus $7.9 \mathrm{~m}^{3} / \mathrm{s}$ ) to total basin population (237135 inhabitants in 2005; INE, 2009), results in the per-capita water availability $\mathrm{Wa}$ of $2766 \mathrm{~m}^{3} / \mathrm{hab} / \mathrm{yr}$, corresponding to a score of 0.25 . In the case of the water-quantity Pressure parameter, the change in $\mathrm{Wa}$ in the 5 year period considered, with respect to the long term average, was $-3.3 \%$, indicating a relatively dry period compared to the mean flow. This, according to Table 1 , resulted in a score of 0.5 . In the case of water-quantity Response parameter, there were moderate investments in water use efficiency improvement, focused on drip irrigation methods at the farm level. Thus, a 0.5 score was attributed to the parameter. Hence, the averaged Pressure, State, and Response parameters for water quantity in the basin for the period studied was $(0.25+0.5+0.5) / 3=0.4$.

In the case of water quality, the Pressure parameter corresponded with the variation in electric conductivity over the 5 year period $(-0.10 \%)$, yielding, according to Table 1, a score of 0.75 . The State parameter (the basin's EC long-term average) was equal to $1525 \mathrm{mmhos} / \mathrm{cm}$, resulting in a score of 0.5 . The Response parameter for water quality resulted in a score of 0.5 , corresponding with a moderate investment rate in sewage treatment in the 5 years studied. The quality average score was therefore $(0.5+0.75+0.5) / 3=0.6$.

Although WSI considers the basin's mean value of the "representative water quality parameter" (in this case, EC), it is important to consider its spatial behaviour. Indeed, the WSI, like many indices, represents a mean value, and although this simplifies the analysis, it may be somewhat 
misleading when spatial or temporal variabilities occur. In the case of the Elqui basin, the EC exhibits great variability throughout the watershed (Figure 2), with especially high values in the Turbio river headwaters, which levels off when using the basin global mean.

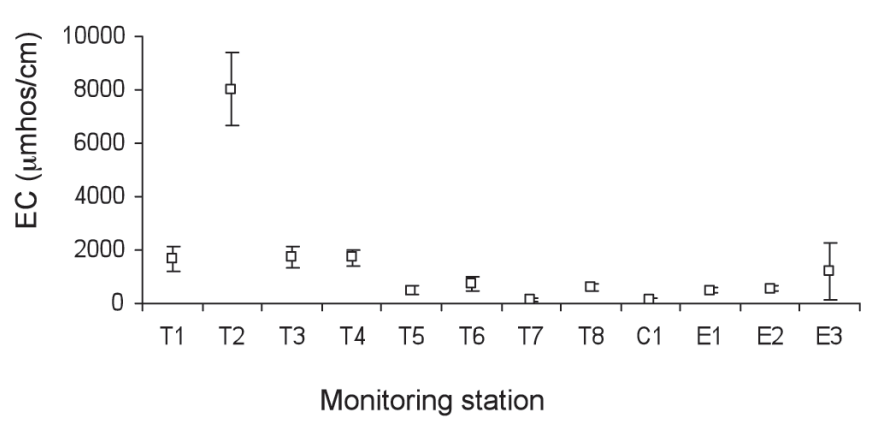

Figure 2: Average long term (1990-2005) electric conductivity $\mathrm{EC}$ in monitoring stations throughout the Elqui basin (vertical bars represent standard deviation)

As an alternative approach, it could be of interest to express the water quality issue in terms of an index rather than as a single parameter. A number of recent studies carried out in various North-Central Chilean basins have demonstrated the potential for this approach (e.g. Espejo et al., 2012).

The overall Hydrology score was the mean of the water quantity and quality scores, i.e., $(0.4+0.6) / 2=0.5$.

\section{Environment Indicator}

Similarly to the Hydrology indicator, the Environment term was obtained as the mean of State, Pressure, and Response. In the case of Pressure, the basin variation in agricultural area and urban population in the period studied was +3.4 and $+8.9 \%$ respectively, yielding an Environment Pressure Index EPI value of $(3.4 \%+8.9 \%) / 2=+6.2 \%$. This corresponds with an environmental Pressure score of 0.5 . In the case of environmental State, the basin maintained more than $70 \%$ of its original vegetation cover between 1997 and 2007 (INE, 2007), and it was therefore assumed to be the same for 2005. This, according to Table 2, resulted in a value of 1.0. However, this score should be used with caution. Indeed, although the natural vegetation cover, represented by prairies, shrubs and small trees, seems high, it is particularly vulnerable to climatic oscillations and to variations in external pressure factors (e.g. goat livestock grazing), as noted in Squeo et al. (2002). Regarding environmental Response, and according to the available data, 817 ha, representing $0.1 \%$ of the Elqui basin area, benefited from the SIRSD-Sustentable Program. According to Table 3, this yields a score of 0.5 . Therefore, the overall score for the Environment indicator was $(0.5+1+0.5) / 3=0.7$.

\section{Life indicator}

The Life-Pressure parameter score in the basin was obtained from the variation in the basin's HDI-Per capita income sub-index in the 5 year period (2001-2005). Over this period, there was a decrease of $-1.4 \%$ in HDI-Income (UNDP, 2003; INE, 2009) resulting, according to Table 1, in a score of 0.5 for this parameter. In the case of LifeState parameter, the basin HDI in the year previous to the period studied was 0.75 , resulting in score of 0.75 . The Life-Response parameter, i.e., the evolution of the HDI in the basin in the period studied, was $0.39 \%$, which yielded a score of 0.5 . The overall Life score for the basin was therefore $(0.5+0.75+0.5) / 3=0.58$.

\section{Policy indicator}

The Policy-Pressure parameter (variation in the HDIEducation sub-indicator in the 5 year period) for the basin was $-7.33 \%$, resulting in a score of 0.5 . This indicates that there was a moderate decrease in the educational level of the basin over the period of analysis. This is an important issue, since problems in education will hinder active, informed, and responsible participation by citizens (societal engagement) in integrated water resources management initiatives and sustainable development efforts. As for Policy-State parameter (basin institutional capacity), although there is a legal framework available (water and environmental laws and regulations), there are problems with the application and enforcement of these laws. Also, basin stakeholders recognize the importance of several water users' organizations in the basin. There are negative perceptions of the level of protection of the basin water resources (in terms of quantity and quality) however. Thus, the basin condition was ranked as "regular" in this respect, with a corresponding score of 0.5 . With regard to Policy-Response, the basin expenditures in water resources management initiatives increased by $331 \%$ in the period analysed, yielding a value of 1.0 for that parameter. Therefore, the overall Policy indicator was the mean of the three policy parameters, i.e., $(0.5+0.5+1) / 3=0.7$. 


\section{Overall watershed sustainability}

The WSI is simply the global mean of the four (H-EL-P) indicators and the Pressure/State/Response columns. Therefore, an overall WSI score of 0.61 was obtained for the Elqui river basin (Table 5).

According to Chaves and Alipaz (2007), the score obtained for the Elqui watershed ranks in the intermediate level of basin sustainability. Additionally, the indicator with the lowest score was Hydrology (0.5), whereas the indicators with the highest scores were Environment and Policy (0.67). In terms of the Pressure, State and Response factors, the lowest score was obtained for Pressure (0.53), and the highest for State (0.66). This indicates that although the current basin conditions (State) are moderately good, there are still pressures threatening basin sustainability.

The parameters considered as "bottlenecks" in the Elqui basin, namely, those which are lower than the overall WSI, are highlighted in Table 5. These parameters in particular must be addressed by water users, stakeholders, and decision makers in order to improve the overall watershed sustainability in the short and long run. It can be seen that a major bottleneck relates to the quantity of water available in the basin. This fact is not surprising for basins in arid or semiarid areas, stressing the need for efficient water management.

\section{Discussion}

The WSI has as advantages its simplicity, flexibility, and adaptability. Also, as with any other index, it could be a useful means for both transmitting information to general audiences and for decision making (Debels et al., 2008). Indeed, sustainability indices such as the WSI can help to provide decision makers with comprehensive information on protection and welfare restoration for the environment and humanity (Lee and Huang, 2007). In particular, they may be especially useful to assess the evolution of basins experiencing rapid change due to demographic or industrial development, as well as to compare the evolution of different basins of a region.

On the other hand, the WSI, in common with other indices (e.g. see Molle and Mollinga, 2003) presents a number of limitations. These are mainly related to difficulties in obtaining up to date local information (i.e. at the watershed level), which probably constitutes one of the major challenges facing implementation of the WSI in developing countries such as Chile.

During the development of the present work it was noticed that there is a certain amount of reluctance by a number of public and private institutions to make information available in the public domain. A similar situation was described, also in the Coquimbo Region, by Aldunce and León (2007) regarding natural risk management issues. This mentality seems to prevail despite the existence in Chile since 2009 of the 20.285 Act on Transparency and Public Information Access, which, at least in theory, should facilitate public access to information (Chilean Government, 2009). In some cases, information is available in different time scales and in periods which are not coincident (e.g. the situation of demographic and agricultural census), which further complicates attempts to apply the index.

As with any index, both the global as well as intermediate scores must be carefully considered (Lee and Huang, 2007; Debels et al., 2008). For example, it is important to re-address the situation of the environmental-State

Table 5: Parameter scores and Watershed Sustainability Index for the Elqui river basin in the period 2001-2005

\begin{tabular}{|c|c|c|c|c|c|c|c|}
\hline & \multicolumn{2}{|c|}{ Pressure } & \multicolumn{2}{|c|}{ State } & \multicolumn{2}{|c|}{ Response } & \multirow[t]{2}{*}{ Result } \\
\hline & Level, \% & Score & Level & Score & Level & Score & \\
\hline \multirow[t]{3}{*}{ Hydrology } & -3.37 & 0.5 & 2,766 & 0.25 & Medium & 0.5 & \\
\hline & -0.10 & 0.75 & 1,525 & 0.50 & Medium & 0.5 & \\
\hline & & 0.63 & & 0.38 & & 0.5 & 0.50 \\
\hline Environment & 7.0 & 0.5 & 0.72 & 1.00 & $0.1 \%$ & 0.5 & 0.67 \\
\hline Life & -1.3 & 0.5 & 0.76 & 0.75 & 0.52 & 0.5 & 0.58 \\
\hline Policy & -7.34 & 0.5 & Medium & 0.50 & $>20 \%$ & 1.00 & 0.67 \\
\hline Result & & 0.53 & & 0.66 & & 0.63 & 0.61 \\
\hline
\end{tabular}


component. As previously explained, a proxy was used for the determination of this component since there are no official protected areas in the Elqui basin currently. The value of 1.0, therefore, may be misleading. A lack of statutory protection results in conditions generally considered unfavourable for sustainable development. According protected status to areas identified as important in terms of biodiversity (CONAMA, 2002) would be highly desirable, both from an environmental point of view as well as in terms of the sustainability of the system.

If the current lack of information is adequately addressed and existing data regularly updated, and if applied within a sustained framework of integrated watershed management supported by a sound public-private alliance, the performance of the WSI could be improved to the extent that it could be considered a useful indicator of basin sustainability.

\section{Conclusions}

A Sustainability Watershed Index of 0.61 was obtained for the Elqui river basin for the period 2001-2005, which can be considered as an intermediate sustainability level. The WSI tool proved to be a useful, simple and adaptable instrument to assess the current state of sustainability of a watershed, suitable as a mean to support decision making processes toward integrated and environmentally oriented watershed management. The bottlenecks and limitations (e.g. Hydrology-State in the case of Elqui) identified in this study represent a window of opportunity to improve the current situation in the basin, and calls for more efficient coordination between the different institutions involved in natural resource management.

The WSI is a holistic index, of great potential for environmental management purposes, given the fact it incorporates social, economic and environmental factors into the sustainability analysis. Indeed, it can be said that this tool, provided it is applied regularly (e.g. every 5 years), can provide a suitable description of the evolution of basin conditions in terms of sustainability, assisting different stakeholders and water managers in the planning, decision-making and implementation of local strategies for sustainable development. Its use as a reference tool is recommended in all cases where definition and enforcement of watershed management plans, and performance verification mechanisms and indices is required.

\section{Acknowledgements}

We thank the commitment of all the institutions, both public and private, that contributed with information and participated in the workshop during the development of this study. Also, we thank Craig Weideman for his proofreading of the English. This work is based on the MSc (Applied Environmental Management) Graduation Project of the first author, and was partially funded by the CAMINAR Project (European Commission, $6^{\text {th }}$ Framework Program, contract number INCOCT2006-032539). This contribution is made as part of the Research Program on Water Resources and Environment (PRHIMA) of the Departamento Ingeniería de Minas, Universidad de La Serena. The paper benefited from the comments of two anonymous reviewers.

\section{References}

Aldunce, P. and León, A. (2007). Opportunities for improving disaster management in Chile: a case study. Disaster Prevention and Management 16 (1), 33 - 41

Amézaga, J., Balvin, D., Abanto, C., Younger, P.L. and Rötting, T.S. (2007). ERMISA and CAMINAR Projects: Research on environmental Regulation, Catchment Management and Mining Impacts in South America. In R. Cidu and F. Frau (Eds) Water in Mining Environments. Mako Edizioni, Cagliari, 307 - 311

Araral, E. (2010). Improving effectiveness and efficiency in the water sector: Institutions, infrastructure and indicators. Water Policy 12 Supplement 1, 1 - 7

Brundtland, G.H. (1987). Our Common Future. The World Commission on Environment and Development. Oxford University Press, USA

Chaves, H.M.L. and Alipaz, S. (2007). An integrated indicator based on basin hydrology, environment, life, and policy: The watershed sustainability index. Water Resources Management 21(5), $883-895$

Chilean Government (2009). Ley de Transparencia, por un Chile más transparente. Ley $N^{0} 20.285$ sobre acceso a la información pública. Available at: http://www.leydetransparencia.gob.cl (Last accessed: May 2011)

CONAMA (2002). Estrategia Regional y Plan de Accion de la 
Biodiversidad IV Region de Coquimbo, Comisión Nacional del Medio Ambiente, Santiago, Chile.

CONAMA (2004). Guía CONAMA para el Establecimiento de las Normas Secundarias de Calidad Ambiental para Aguas Continentales Superficiales y Marinas. Comisión Nacional del Medio Ambiente, Santiago, Chile

CONAMA (2007). Estrategia Nacional de Gestion Integrada de Cuencas Hidrograficas. Comisión Nacional del Medio Ambiente, Santiago, Chile.

CONAMA (2009). Política para la Conservación y Protección de Glaciares. Comisión Nacional del Medio Ambiente, Santiago, Chile. Available at http://www.conama.cl/portal/1301/articles-45467_ PoliticaGlaciales.pdf (Last accessed: December 2009)

Cortés, A.E. (2010). Determinación de un indice de sustentabilidad de cuencas (WSI) para la cuenca hidrográfica del río Elqui (Cuenca HELP-UNECO). MSc Thesis, Universidad Católica del Norte, Coquimbo, Chile

Debels, P., Szlafsztein, C., Aldunce, P., Neri, C., Carvajal, Y., Quintero-Angel, M., Celis, A., Bezanilla, A. and Martínez, D. (2008). IUPA: a tool for the evaluation of the general usefulness of practices for adaptation to climate change and variability. Natural Hazards 50 (2), 211 - 233

Espejo, L., Kretschmer, N., Oyarzún, J., Meza, F., Núñez, J., Maturana, H., Soto, G., Oyarzo, P., Garrido, M., Suckel, F., Amezaga, J. and Oyarzún, R. (2012). Application of water quality indices and analysis of the surface water quality monitoring network in semi-arid North Central Chile. Environmental Monitoring and Assessment 184 (9), 5571-5588

Galleguillos, G. (2004). Efectos de la Actividad Minera y de las obras hidraulicas en la calidad de las aguas del Rio Elqui y de sus afluentes. Memoria de Título, Ingeniero Civil Ambiental, Universidad de La Serena, La Serena, Chile

Galleguillos, G., Oyarzún, J., Maturana, H. and Oyarzún, R. (2008). Retención de arsénico en embalses: el caso del río Elqui, Chile. Ingeniería Hidráulica en Mexico 23, 29 - 36

Guevara, S., Oyarzún, J. and Maturana, H. (2006). Geoquímica de las aguas del río Elqui y de sus tributarios en el período 19751995: Factores naturales y efecto de las explotaciones mineras en sus contenidos de Fe, $\mathrm{Cu}$, y As. Agricultura Técnica (Chile) 66 (1), 57 - 69
Hezri, A.A. and Hassan, M.N. (2006). Towards sustainable development? The evolution of environmental policy in Malasia. Natural Resources Forum 30 (1), 37 - 50

Higueras, P., Oyarzun, R., Oyarzún, J., Maturana, H., Lillo, J. and Morata, D. (2004). Environmental assessment of coppergold-mercury mining in the Andacollo and Punitaqui districts, northern Chile. Applied Geochemistry 19 (11), 1855 - 1864

Hooper, B. (2010). River basin organization performance indicators: Application to the Delaware River basin commission. Water Policy 12, 461 - 478

INE (2007). Censo agropecuario. Instituto Nacional de Estadistica, Santiago, Chile. Available at: http://www.ine. cl/canales/chile_estadistico/censos_agropecuarios /censo_ agropecuario_07.php (Last accessed: November 2009).

INE (2009). Estadística demográfica. Instituto Nacional de Estadistica, Santiago, Chile. Available at: www.ine.cl (Last acessed: November 2009)

INN (1987). Norma Chilena Oficial, Requisitos de Calidad de Agua para Diferentes Usos (NCh133.Of78). Instituto Nacional de Normalización, Santiago, Chile

Jannas, R.R., Bowers, T.S., Petersen, U. and Beane, R.E. (1999). High -sulfidation deposit types in the El Indio district, Chile. Society of Economic Geologists, Special Publication 7, 27 - 59

Kalthoff, N., Fiebig-Wittmaack, M., Meibner, C., Kohler, M., Uriarte, M., Bischoff-Gaub, I. and Gonzales, E. (2006). The energy balance, evapo-transpiration and nocturnal dew deposition of an arid valley in the Andes. Journal of Arid Environment 65 (3), 420 - 443

Ledoux, L., Mertens, R. and Wolff, P. (2005). EU sustainable development indicators: An overview. Natural Resources Forum 29 (4), 392 - 403

Llanca, J.C. y Miranda, E.E. (2003). Estudio de agua subterránea en la cuenca del río Elqui. Memoria de Título Ingeniero Civil Ambiental, Universidad de La Serena, La Serena, Chile

Lee, Y.J. and Huang, C.M. (2007). Sustainability index for Taipei. Environmental Impact Assessment Review 27 (6), 505 - 521

Lostarnau, C., Oyarzún, J., Maturana, H., Soto, G., Señoret, M., Soto, M., Rötting, T.S., Amezaga, J.M. and Oyarzún, R. (2011). 
Stakeholder participation within the public environmental system in Chile: Major gaps between theory and practice. Journal of Environmental Management 92 (10), 2470 - 2478

Machinea, J.L., Barcena, A. and Leon, A. (2005). Objetivos de Desarrollo del Milenio: una mirada desde America Latina y el Caribe. CEPAL, Santiago, Chile

Molle, F. and Mollinga, P. (2003). Water poverty indicators: Conceptual problems and policy issues. Water Policy 5, 529 - 544

OECD (2003). OECD environmental indicators: development, measurement and use. Organization for Economic Cooperation and Development. Paris, France.

Oyarzun, R., Ortega, L., Sierra, J., Lunar, R. and Oyarzun, J. (1998). Cu, Mn, and Ag mineralization in the Quebrada Marquesa Quadrangle, Chile: the Talcuna and Arqueros districts. Mineralium Deposita 33 (6), 547 - 559

Oyarzun, R., Lillo, J., Higueras, P., Oyarzún, J. and Maturana, H. (2004). Strong arsenic enrichment in sediments from the Elqui watershed, Northern Chile: industrial (gold mining at El IndioTambo district) vs. geologic processes. Journal of Geochemical Exploration 84 (2), 53 - 64

Oyarzun, R., Guevara, S., Oyarzún, J., Lillo, J., Maturana, H. and Higueras, P. (2006). The As-contaminated Elqui river basin: a long lasting perspective (1975-1995) covering the initiation and development of $\mathrm{Au}-\mathrm{Cu}-\mathrm{As}$ mining in the high Andes of northern Chile. Environmental Geochemistry and Health 28 (5), 431-443

Oyarzun, J., Maturana, H., Paulo, A. and Pasieczna, A. (2003). Heavy metals in stream sediments from the Coquimbo Region (Chile): Effects of sustained mining and natural processes in a semiarid Andean basin. Mine Water and Environment 22, 155 - 161

Paskoff, R. (1993). Geomorphology of Semiarid Chile. Universidad de La Serena, La Serena, Chile.

Perlack, R.D., Ensminger, T. and Martínez, R. (2001). Guatemala strives for environmental and economic sustainability in the Rio Dulce Region. Natural Recources Forum 25, 235 - 244
Saravanan, V.S., McDonald, G.T. and Molling, P.P. (2009). Critical review of integrated water resources management: moving beyond polarised discourse. Natural Resources Forum 33 (3), 76 - 86

Squeo, F., Arancio, G. and Gutierrez, J. (2002). Libro rojo de la flora nativa y de los sitios prioritarios para su conservación: Región de Coquimbo. Universidad de La Serena, Corporacion Nacional Forestal y Gobierno Regional de Coquimbo. La Serena, Chile.

Sullivan, C.A. Meigh, J.R., Giacomello, A.M., Fediw, T., Lawrence, P., Samad, M., Mlote, S., Hutton, C., Allan, J.A., Schulze, R.E., Dlamini, D.J.M., Cosgrove, W., Delli Priscoli, J., Gleick, P., Smout, I., Cobbing, J., Calow, R., Hunt, C., Hussain, A., Acreman, M.C., King, J., Malomo, S., Tate, E.R., O’Regan, D., Milner, S. and Steyl, I. (2003). The Water Poverty Index: Development and application at the community scale. Natural Resources Forum 27 (3), 189 - 199

UNDP (1994). Informe sobre el Desarrollo Humano. Programa de la Naciones Unidas para el Desarrollo y Fondo Cultura Economica FCE, México

UNDP (2003). Las trayectorias del desarrollo humano en las comunas de Chile (1994-2003). Temas de desarrollo humano sustentable No 11, Santiago, Chile

UNESCO (2008). Evaluación objetiva de la aplicación y cálculo del Índice de Sostenibilidad de Cuenca en la Cuenca Hidrográfica del Canal de Panamá. Documentos Técnicos del PHI-LAC, N ${ }^{\mathrm{o}} 12$

UNESCO (2010). Guía metodológica para la aplicación del Análisis Regional de Frecuencia de Sequías basado en L-momentos y resultados de aplicación en América Latina. CAZALAC. Documentos Técnicos del PHI-LAC, No 27. Available at: http://www.unesco.org/new/en/natural-sciences/ environment/water/ihp/ihp-programmes/help/ (Last accessed: May 2011)

WHO (2008). Guidelines for Drinking-Water Quality. World Health Organization. Available at: http:/www.who.int/water sanitation_health/dwq (Last acessed: December 2008) 